\title{
Relative incidence of Corynebacterium vaginale (Haemophilus vaginalis), Neisseria gonorrhoeae, and Trichomonas spp. among women attending a venereal disease clinic $^{(1)}$
}

\author{
W. E. DUNKELBERG (2), JR., R. SKAGGS, \\ D. S. KELLOGG, JR., AND G. K. DOMESCIK \\ From the Venereal Disease Research Laboratory, Venereal Disease Branch, \\ State and Community Services Division, National Communicable Disease Center, \\ Health Services and Mental Health Administration, Public Health Service, \\ U.S. Department of Health, Education, and Welfare, and \\ the Third U.S. Army Medical Laboratory, Fort McPherson, Atlanta, Georgia 30330, U.S.A.
}

Corynebacterium vaginale (Haemophilus vaginalis) (Gardner and Dukes, 1955; Zinnemann and Turner, 1963 ) is believed to be a sexually transmitted organism responsible for a commonly occurring mild vaginitis. It is carried asymptomatically in the anterior urethrae of infected men but has been associated with a few cases of non-gonococcal urethritis (Leopold, 1953; Dunkelberg and Woolvin, 1963; Mehta, Rana, and Vaishnav, 1967).

Cultivation on blood agars led Gardner and Dukes (1955) to classify it as a member of genus Haemophilus, but Zinnemann and Turner (1963) reported that when grown on inspissated serum slopes the organism is Gram-positive, and they recommended its reclassification as $C$. vaginale. The growth requirements were determined by Dunkelberg and $\mathrm{McVeigh}$ (1969) and do not include blood, serum, haem, DNA, or other definable coenzyme-like substances. Growth difficulties were encountered with some peptones, but this was attributed to the extensive B-vitamin and nucleic acid base requirements of the bacillus.

Previous incidence studies on $C$. vaginale were conducted among populations of women at obstetric and gynaecological clinics, patients reporting to physicians in private practice, or women undergoing physical examinations for employment. Dunkelberg, Hefner, Patow, Wyman, and Orup (1962) found that the incidence in asymptomatic married American Negro women was 24.4 per cent., whereas that in asymptomatic married white women was 9.5 per cent. Lewis and O'Brien (1969) reported an incidence of 36.7 per cent. among Negro women attending cancer

Received for publication September 16, 1969

(1) Trade names are used for identification only and do not represent an endorsement by the Public Health Service or the U.S. Department of Health, Education, and Welfare.

(2) Guest Researcher 1969 at the Venereal Disease Research Laboratory and gynaecological clinics in North Carolina. White patients attending the same clinic had an incidence rate of $25 \cdot 7$ per cent. Desai, Vaishnav, and Ankleshwaria (1966) studied 183 women attending an obstetric and gynaecological clinic in India and reported that 28.4 per cent. carried trichomonads and 14.2 per cent. $C$. vaginale. These figures include 5 per cent. with mixed flora. In Great Britain, Frampton and Lee (1964) reported that 25 per cent. of women with vaginitis had $C$. vaginale, compared to 21 per cent. of an asymptomatic group.

The highest reported incidence of $C$. vaginale was 52 per cent. among 200 Hungarian women reporting to the receiving ward of a hospital (Pintér, Csorba, and Zékány, 1962). The lowest reported rate was 6 per cent. among women in a Paris hospital (Bret and Cohen-Debray, 1959). However, these investigators utilized a transport broth containing penicillin which may have impaired the survival of $C$. vaginale. Frampton and Lee (1964) reported that all their tested isolates of $C$. vaginale were sensitive to disks containing 1 unit of penicillin. A study of 55 married Vietnamese women reporting for physical examination before employment gave an incidence of 7 per cent. (Dunkelberg and Scherman, 1969).

The present study was conducted to determine the relative incidence of $C$. vaginale, Neisseria gonorrhoeae, and Trichomonas spp. among women attending a venereal disease clinic. We are unaware of any previous studies of this nature on a similar population.

\section{Material and methods \\ Population surveyed}

A total of 200 women initially reporting to the Fulton County Health Department in Atlanta, Georgia, were satisfactorily examined and cultures obtained. The majority were contacts named by gonorrhoea-infected 
consorts, but some attended spontaneously because they thought that they might be infected.

By race, 172 (86 per cent.) were Negro and 28 (14 per cent.) were white. The age range was 12 to 67 years (average 24.7). The group was composed predominantly of low-income, mobile young women. The degree of promiscuity of such a group is difficult to characterize. Patients were questioned about the numbers of their recent sexual contacts and the answers gave the impression that approximately half were promiscuous and half were sexually conservative women who had become exposed to risk of gonococcal infection by contact with errant husbands or boyfriends. Individuals were not questioned about their possible involvement in prostitution. It is thought that the local prostitutes are treated for gynaecological complaints by private physicians. Culture methods

All specimens were obtained by the attending medical officer or clinic nurses. The vagina and cervix were inspected by the introduction of a bivalve speculum, and any mucus present was removed from the cervical os with a cotton swab and discarded. The speculum blades were compressed slightly around the cervix while expressed matter was collected on a cotton swab. The swab was then rolled in a ' $Z$ ' movement over Thayer-Martin (TM) medium (Martin, Billings, Hackney, and Thayer, 1967) TM plates were stored in candle extinction jars at $36^{\circ} \mathrm{C}$. until the collections were completed.

Another swab was pressed against various areas of the posterior vaginal fornix. This swab and the cervical swab were then placed together in a transport test tube containing $2 \mathrm{ml} .1 .5$ per cent. Difco $\nmid$ Proteose Peptone No. 3 in distilled water, $\mathrm{pH} 6.8$ before sterilization. TM plates, swabs, and survey study forms were sent daily to the Venereal Disease Research Laboratory, National Communicable Disease Center. The longest period between collection of specimens and laboratory processing was 5 hours.

At the Laboratory, cervical exudates on TM medium were further streaked out, placed in candle extinction jars, and incubated at $36^{\circ} \mathrm{C}$. After 18 to 24 hours' incubation, TM plates were examined for gonococci $(C$. vaginale does not grow on TM medium). Colonies having a typical morphology, giving a positive oxidase test, and consisting of Gram-negative diplococci were presumptively designated $N$. gonorrhoeae. Cells from these colonies were exposed to fluorescein-labelled antigonococcal rabbit globulins which had been absorbed with meningococcal cells to render the conjugate specific for gonococci. $\ddagger$ Cells having a $2+$ or greater fluorescence were considered to be confirmed as $N$. gonorrhoeae.

A few drops of material from the transport medium tube were examined in wet mount, and fixed slides were stained by Gram's method. Those wet preparations showing organisms with characteristic flagellate action were listed as positive for Trichomonas spp. The finding of 'clue cells' in wet mounts and many Gram-negative and Gram-variable bacilli associated with epithelial cells

†Difco Laboratories, Detroit, Michigan, U.S.A.

tAntiserum courtesy of W. L. Peacock, Jr., Venereal Disease Research Laboratory. in stained preparations marked a specimen as suspect for C. vaginale. 'Clue cells' were defined by Gardner and Dukes (1955) as vaginal epithelial cells having a granular appearance in wet mounts due to $C$. vaginale being uniformly spaced upon the surface of the cells.

Both swabs were streaked on Peptone-Starch-Dextrose (PSD) medium, containing 1.5 per cent. agar (Dunkelberg and McVeigh, 1969). The original formula called for 1.5 per cent. Proteose Peptone No. 3, but we have now increased this to $2 \cdot 0$ per cent. PSD plates were incubated at $36^{\circ} \mathrm{C}$. for 48 hours in candle extinction jars. After incubation, plates were examined for colonies typical of $C$. vaginale by means of a stereoscopic microscope $(40 \times)$ with a substage light source. Suspect $C$. vaginale colonies were transferred to fresh PSD agar plates and re-incubated for 48 hours. Growth was then examined for colony and cellular morphology, reaction to a loopful of 3 per cent. $\mathrm{H}_{2} \mathrm{O}_{2}$ on PSD agar plates, catalase reaction, and sugar fermentation reactions as previously described (Dunkelberg, Skaggs, and Kellogg, 1970). Those isolates which showed typical colonial and cellular morphology, inhibition by $\mathrm{H}_{2} \mathrm{O}_{2}$, negative catalase reaction, weak-tomoderate fermentation of dextrose, and moderate-tostrong fermentation of maltose and starch were reported as $C$. vaginale.

\section{Results}

C. vaginale was isolated from 62 ( 31 per cent.) of the 200 women surveyed, $N$. gonorrhoeae from 80 (40 per cent.), and Trichomonas spp. were observed in 113 (56.5 per cent.) of the wet mounts. These findings are shown in Table $I$.

TABLE I Incidence of organisms among 200 women at a venereal disease clinic

\begin{tabular}{lrll}
\hline Organism & No. & Percentage \\
\cline { 1 - 1 } C. vaginale & 62 & $31 \cdot 0$ \\
N.gonorrhoeae & & 80 & $40 \cdot 0$ \\
Trichomonas spp. & 113 & 56.5 \\
\hline
\end{tabular}

Only 45 (22.5 per cent.) of the group failed to yield one or more of the species sought. Single and combined infections are presented in Table II. Those with $C$. vaginale alone numbered 14 (7 per cent.),

TABLE II Compilation of single and combined infections

\begin{tabular}{|c|c|c|}
\hline Organism & No. & Percentage \\
\hline $\begin{array}{l}\text { C. vaginale only } \\
\text { C. vaginale }+N \text {. gonorrhoeae } \\
\text { C. vaginale }+ \text { Trichomonas spp. } \\
\text { C. vaginale }+N \text {. gonorrhoeae }+ \text { Tricho- } \\
\text { monas spp. } \\
N . \text { gonorrhoeae only } \\
N . \text { gonorrhoeae }+ \text { Trichomonas spp. } \\
\text { Trichomonas spp. only } \\
\text { None }\end{array}$ & $\begin{array}{l}14 \\
11 \\
22 \\
15 \\
17 \\
37 \\
39 \\
45\end{array}$ & $\begin{array}{r}7.5 \\
8.5 \\
18.5 \\
19.5 \\
22.5\end{array}$ \\
\hline Total & 200 & $100 \cdot 0$ \\
\hline
\end{tabular}


combined with $N$. gonorrhoeae 11 (5.5 per cent.), and combined with trichomonads 22 (11 per cent.). Fifteen ( 7.5 per cent.) patients harboured all three organisms.

The largest number of single infections occurred among those with Trichomonas spp., numbering 39 (19.5 per cent.). The gonococcus was present with trichomonads in 37 (18.5 per cent.) patients, and 17 (8.5 per cent.) yielded gonococci alone.

\section{Discussion}

Like trichomoniasis, C. vaginale infection seems to qualify as a sexually transmitted disorder. Its discoverer, Leopold (1953), found it especially significant that husbands of infected wives showed a high incidence of positive urine cultures. Gardner and Dukes (1955) recovered the bacillus from the anterior urethrae of over 90 per cent. of husbands whose wives were infected. Infected males are usually asymptomatic, whereas symptoms in women are moderate or absent.

The reported incidence of $C$. vaginale among women considered at low risk for venereal disease varies from 6 to 52 per cent. Factors previously considered directly responsible for variations in incidence are racial composition, socioeconomic status, sexual habits, and criteria for identification of the bacillus. Gardner (1967) reported the incidence of vaginitis developing among human volunteers inoculated with pure cultures of $C$. vaginale to be approximately one-third. It is not possible to determine the number of women in our survey who had venereal contact with $C$. vaginale-infected men, but we think it reasonable to suppose that almost all have been exposed to this organism at some time and that many of them are at frequent risk. Yet the incidence of $C$. vaginale among this population is no higher than that found in surveys among women considered to be at low risk of infection with venereal diseases.

Three factors might account for this. Our methods for determination of $C$. vaginale in this study were more strict than those used by most authors in the past. Previous workers utilized blood agars which preclude microscopical examination of colonial morphology by transmitted light. Some researchers have depended on 'clue cell' findings alone or combined with cultivation of Gram-negative and Gramvariable bacilli on blood agars. We find that many diphtheroid-like isolates are Gram-negative or Gramvariable on initial isolation, some remain so through subculture, and many produce no detectable catalase. $C$. vaginale is a catalase-negative, predominantly Gram-negative, coryneform rod; but it can be differentiated from unclassified diphtheroids by its colony morphology and biochemical reactions.

A second, more objective factor tending to keep the incidence rate below that of $N$. gonorrhoeae and Trichomonas spp. in a population at high risk for venereal disease is the low virulence of $C$. vaginale. Criswell, Ladwig, Gardner, and Dukes (1969) inoculated nine human volunteers intravaginally with $2 \times 10^{10}$ organisms of type strain 594 which had been cultured for 12 hours. Vaginitis developed in five subjects. They inoculated twenty other women with 24-hour-old cultures of several $C$. vaginale strains, and only two of them developed vaginitis. The inoculum utilized seems to have contained many more organisms than would be transferred from an infected male urethra during coitus.

The number of $C$. vaginale organisms supported in male urethrae may be limited by available carbohydrate and by frequent urinary flushing. Edmunds (1962) recognized that the main energy source of the bacterium is the glycogen of the vaginal and urethral epithelium. The glycogen content of male urethral epithelium appears to be much less than that of vaginal epithelium, as demonstrated by staining fixed smears containing epithelial cells with iodine solution.

Thirdly, reference strains of $C$. vaginale ferment the carbohydrates in PSD medium, and the terminal acid values are usually pH 3.8 to 4.5 (Dunkelberg and McVeigh, 1969). Daily transfer of organisms is necessary to ensure viability. Gardner and Dukes (1955) reported that the vaginal environment of women infected with $C$. vaginale is usually at $\mathrm{pH}$ 5.0 to 5.5 , whereas normal women have a vaginal $\mathrm{pH}$ of 4.0 to $4 \cdot 7$. This suggests that women who maintain a normal vaginal $\mathrm{pH}$ are unlikely to become hosts of $C$. vaginale unless they become infected when vaginae are more alkaline because of menstruation, prior infection with trichomonads, or some other cause. Thus, the percentage of women susceptible to infection by this organism remains fairly constant.

\section{Summary}

A survey was made among 200 women attending a venereal disease clinic in Atlanta, Georgia, to determine the relative incidence of Corynebacterium vaginale, Neisseria gonorrhoeae, and Trichomonas spp. $C$. vaginale had the lowest incidence ( 31 per cent.), followed by $N$. gonorrhoeae (40 per cent.), and trichomonads ( 56.5 per cent.). Mixed infections were common. The incidence of $C$. vaginale among the population surveyed is approximately that of populations not considered to be at high risk of contracting venereal diseases. The authors postulate that this is due to the low virulence of $C$. vaginale, the limited numbers of organisms maintained in infected male 
urethrae, and the detrimental effect of normal vaginal $\mathrm{pH}$ on the bacillus.

\section{References}

Bret, A. J., and Cohen-Debray (1959) Presse méd., 67, 1611

Criswell, B. S., Ladwig, C. L., Gardner, H. L., and Dukes, C. D. (1969) Obstet. and Gynec., 33, 195

Desai, Z. D., Vaishnav, V. P., and ANKLeshwaria, S. B. (1966) f. Postgrad. Med. (Bombay), 12, 91

Dunkelberg, W. E., Jr., Hefner, J. D., Patow, W. E., WYMAN, F. J., Jr., and ORUP, H. I. (1962) Obstet. and Gynec., 20, 629

and McVeIGH, I. (1969) Antonie van Leeuwenhoek, 35, 129

and Scherman, B. M. (1969) U.S. Army Medical Research Team (WRAIR), Vietnam: Annual Progress Report (Washington)

-, Skaggs, R., and Kellogg, D. S., Jr. (1970) Appl. Microbiol., 19, 47

- and Woolvin, S. C. (1963) Milit. Med. (Wash.), 128, 1098

Edmunds, P. N. (1962) f. Path. Bact., 83, 411

Frampton, J., and LEE, Y. (1964) $\mathcal{f}$. Obste ${ }^{t}$. gynaec. Brit. Cwlth, 71, 436.

GARDNER, H. L. (1967) F. Miss. St. med. Ass., 8, 529

- - and Dukes, C. D. (1955) Amer. F. Obstet. Gynec., 69, 962

LEOPOLD, S. (1953) U.S. armed Forces med. F., 4, 263

LewIS, J. F., and O'BrIEN, S. M. (1969) Amer. F. Obstet. Gynec., 103, 843
Martin, J. E., Billings, T. E., Hackney, J. F., and Thayer, J. D. (1967) Publ. Hlth Rep. (Wash.), 82, 361 Mehta, U. S., RaNA, V. S., and VaISHNAV, V. P. (1967) Indian F. Path. Bact., 10, 170

Pintér, M., Csorba, L., and ZéránY, G. (1962) Orv. Hetil., 103, 585

Zinnemann, K., and Turner, G. C. (1963) F. Path. Bact, 85, 213

Incidence relative de Corynebacterium vaginale (Haemophilus vaginalis), de Neisseria gonorrhoeae et de diverses espèces de Trichomonas parmi les femmes consultantes dans une clinique de maladies vénériennes

\section{SOMMAIRE}

Une enquête fut faite chez 200 consultantes d'une clinique vénéréologique d'Atlanta, Géorgie, pour déterminer l'incidence relative de Corynebacterium vaginale, de Neisseria gonorrhoeae et de diverses espèces de Trichomonas. C. vaginale se présenta avec la plus faible incidence (31 pour cent), suivi par $N$. gonorrhoeae puis par les trichomonas (56 pour cent). Les infections mixtes furent fréquentes. L'incidence de $C$. vaginale dans le groupe examiné est à peu près celui de groupes considérés comme non exposés à un haut risque de contamination vénérienne. Les auteurs considèrent que ceci est dû à la faible virulence de $C$. vaginale, au petit nombre d'organismes hébergés dans l'urètre des hommes infectés et à l'effet préjudiciable du $\mathrm{pH}$ vaginal normal sur le bacille. 